\title{
SOCIO-DEMOGRAPHIC CORRELATES OF DENTAL ANXIETY AMONG PATIENTS ATTENDING A PUBLIC DENTAL CLINIC IN LAGOS, NIGERIA
}

\author{
Afolabi Oyapero ${ }^{1}$, Ogunbanjo B Ogunbiyi \\ 1) Department of Preventive Dentistry, Lagos State University Teaching Hospital, Ikeja, Lagos. \\ 2) Department of Child Dental Health, Lagos State University Teaching Hospital, Ikeja, Lagos.
}

\section{ARTICLE INFORMATION:}

\section{Article History:}

Received 07 February 2016

Accepted in revised form: 15 September 2016

Published:12 December 2016

Corresponding author:

Afolabi Oyapero

e-mail: fola_ba@yahoo.com

Keywords:

Socio-demographic correlation, Anxiety, Patients, Dental clinic, Nigeria

\begin{abstract}
ABSTRCAT:
Aim: Dental anxiety is a subjective state of feelings that is associated with impending danger even when the stimulus or threat is not immediately present or readily identifiable. It has been ranked fifth among commonly feared situations. In Nigeria however, limited studies have been conducted in this field thus far with only one identified study using the Modified Dental Anxiety Scale. The aim of this study therefore was to assess the level of dental anxiety in dental patients attending the Lagos State University Teaching Hospital, Ikeja (LASUTH) using the Modified Dental Anxiety Scale (MDAS).

Materials and Methods: This cross-sectional study was conducted at LASUTH. A structured interviewer administered questionnaire was used for data collection. Results: The prevalence of dental anxiety was $20.5 \%$ while the prevalence of extreme anxiety of $4.1 \%$. Having a local anaesthetic (MDAS $\geq 15=24.6 \%$ ) and having a tooth drilled (MDAS $\geq 15=21.3 \%$ ) were most associated with dental anxiety. The best predictors for dental anxiety from this study were, in descending order, age, education, marital status and gender.

Conclusion: A rapid screening tool such as the MDAS could be routinely applied on prospective dental patients to determine their level of anxiety. Appropriate non-pharmacologic and pharmacologic strategies could then be targeted at vulnerable respondents to make their dental experience as pleasant as possible.
\end{abstract}

الملخص العربي: - - (المص

ارتباط العوامل الاجتماعية والديموغرافية والقلق من علاج الأسنان بين المرضى الإنى الذين يراجعون عيادة الأسنان العامة في لاغوس، الإني، نيجيريا

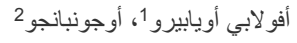

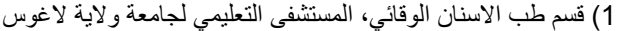
2) قسم طب أسنان الاطفال، المستثفى التعليمي لجامعة ولاية لاغوس ولاني لاغن

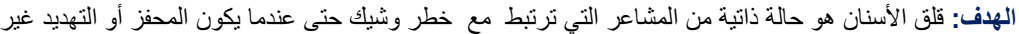

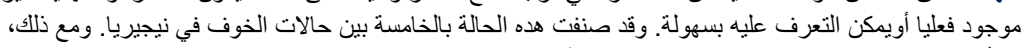

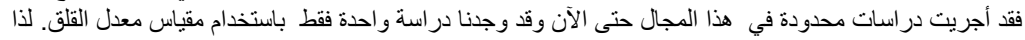

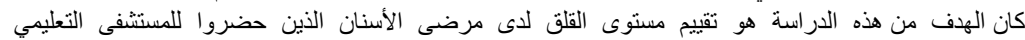

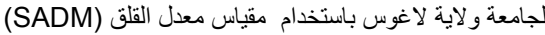
المواد و الطرق: أجريت هذه الدراسة المستعرضة في ليسوتو وقد نم استخدام المقابلة الني تدار بإستبيان لجمع

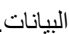

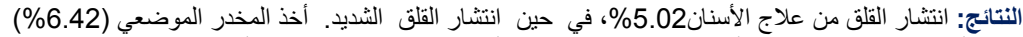

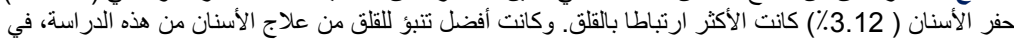

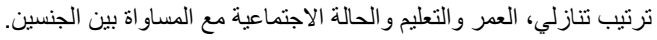

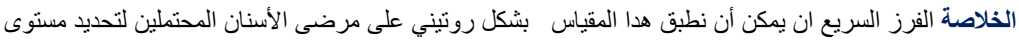

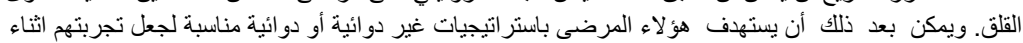

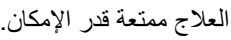

Copyright $\odot$ 2016. LDJ. This is an open access article distributed under the Creative Commons Attribution 3.0 License, which permits unrestricted use, distribution, and reproduction in any medium, provided the original work is properly cited.

Citation: Libyan Dent J 2016, 6: 26021031 - http://dx.doi.org/10.5542/LDJ.v6i0. 26021031 


\section{INTRODUCTION}

Dental anxiety is the abnormal fear of receiving dental care and also a subjective state of feelings that is associated with impending danger even when the stimulus or threat is not immediately present or readily

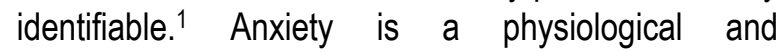
psychological state characterized by cognitive, physiological and behavioral components. ${ }^{2}$ Dental anxiety has been ranked fifth among commonly feared situations. ${ }^{3}$ Factors that have been consistently linked with a greater incidence of dental anxiety include personality characteristics, fear of pain, past traumatic dental experiences and the influence of dentally anxious family members. ${ }^{4,5}$

The fear of pain has been strongly linked to the development of dental anxiety and to the avoidance of dental treatment. Despite the technological advances made in modern dentistry, anxiety about dental treatment and the fear of pain associated with it remain widespread.$^{6}$ Dental anxiety has an impact on the burden oral diseases and oral health seeking behaviour. It is the most common reason for not attending the dental clinic. ${ }^{7}$ Dentally anxious individuals tend to avoid regular and conventional care, and thus rely on self-care, emergency services and traditional or alternative remedies to relieve dental pain.$^{8}$ It partially limits or completely prevents the utilization of oral healthcare services and it increases the prevalence of dental diseases.$^{9}$

There is a general agreement that dental anxiety is acquired at a young age especially during adolescence. ${ }^{10}$ Locker et al. ${ }^{11}$ found that prevalence of dental anxiety increased only marginally between the ages of 15 and 18 years. Many cross-sectional studies have documented that the prevalence of dental anxiety reduces with age. ${ }^{12-14}$ Similar declines in other general and specific phobias with age were also found in this study. There are higher prevalence rates for dental anxiety in females and ${ }^{15}$ poorly educated people from lower socio-economic backgrounds ${ }^{16}$

A wide range of validated questionnaires have been used to assess dental anxiety. These include the Modified Dental Anxiety Scale (MDAS), the Dental Concerns Assessment (DCA) and the Index of Dental
Anxiety and Fear (IDAF-4C+). The MDAS is considered to be a simple method for quantitative assessment and it is a valid and reliable instrument. ${ }^{17}$ Dental anxiety has a high prevalence in many western countries. ${ }^{18,19}$ In Nigeria however, limited studies $^{20,21}$ have been conducted in this field thus to determine the prevalence of dental anxiety with its socio-demographic correlates. Only one study was identified that used the MDAS as a screening tool. The aim of this study therefore was to assess the level of dental anxiety in dental patients attending the Lagos State University Teaching Hospital, Ikeja using the MDAS.

\section{MATERIALS AND METHODS}

This cross-sectional study was conducted at the Lagos State University Teaching Hospital, Ikeja.

\section{Sample size}

The sample size was calculated using a formula for cross sectional studies: $\quad \mathrm{N}=\mathrm{Z} \mathrm{pq} / \mathrm{d} 2$. Using a prevalence value of $7.3 \%$ from a similar Nigerian study, ${ }^{21}$ a sample size of 53 was determined. One hundred and twenty two subjects were however recruited for the study to increase the power of the study.

\section{Sample selection}

The subjects for the study were recruited from patients on treatment appointment at the Dental clinic of LASUTH. A simple random sampling technique was utilized to recruit the respondents. The sampling frame was the attendance register for each day and the balloting method was utilized in selecting the study subjects. A total of 122 questionnaires were administered during the study on subjects who met the informed criteria and gave their informed consent.

\section{Inclusion and exclusion criteria}

Included in the study were patients who were 18 years old and above and were willing to give their informed consent. Those who were unwilling to give their informed consent, patients who had obvious anxiety disorders and those who were debilitated were excluded from the study.

\section{Data collection}

A structured interviewer administered questionnaire 
was used for data collection. The questionnaire consisted of questions on socio-demographic items including sex, age, and level of education, as well as the level of anxiety using the MDAS.

\section{Anxiety questionnaire}

The MDAS is a 5 -item questionnaire which measures dental anxiety on a 5 scale standardized answer scheme with responses ranging from 1 (Not anxious) to 5 (Extremely anxious), with 25 being the maximum obtainable score by a respondent. The first 2 questions focused on the anticipation of dental treatment while the last 3 focused on aspects of dental treatment. These subjects were further divided as being dentally anxious and extremely anxious about going to see the dentist based on the MDAS scores of $\geq 15$ and $\geq 19$ respectively.

\section{Data analysis}

Data analysis was performed using SPSS (version 20 ,SPSS, Chicago III.). Descriptive statistics such as mean and standard deviation (SD) for continuous variables and frequency and percentage for categorical variables were determined. The Anova WAMW ZDV XYHG FRP SDH WWH VRFRGP RJIDSKIFYDUDEON RI SDUHQNVXFKIDVIJHQGHUDJHand education levels

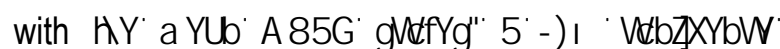

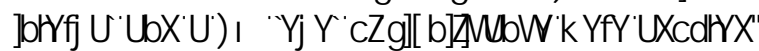

\section{RESULTS}

\section{Socio-demographic characteristics}

Female respondents made up $50.8 \%$ in the study while male respondents made up $49.2 \%$. The highest percentage of respondents was in the 31-40 years age group making up $29.5 \%$ of the respondents, while those aged 21-30 years were $27.9 \%$ making up the second largest category. Majority of the respondents (59\%) had a university education while single subjects (54.1\%) made up the largest percentage.

\section{Prevalence of dental anxiety in the studied population using MDAS}

The prevalence of dental anxiety was $20.5 \%$ while the prevalence of extreme dental anxiety was $4.1 \%$. For the responses to the 5 questions in the MDAS, having a local anaesthetic (MDAS $\geq 15=24.6 \%$ ) and having a tooth drilled (MDAS $\geq 15=21.3 \%$ ) were most associated with dental anxiety while sitting in the waiting room (MDAS $\geq 15=11.5 \%$ ) and having scaling and polishing done (MDAS $\geq 15=8.2 \%$ ) were least associated with dental anxiety (Table 1).

Table 1: Prevalence of dental anxiety in the studied population using MDAS

\begin{tabular}{|c|c|c|c|c|c|c|}
\hline \multirow[t]{3}{*}{ Anxiety category } & \multicolumn{2}{|c|}{ Not anxious } & \multicolumn{2}{|c|}{ Dentally anxious } & \multicolumn{2}{|c|}{ Extremely anxious } \\
\hline & MDAS: & $0-14$ & MDAS: & $15-25$ & MDAS: & $19-25$ \\
\hline & $\mathbf{n}$ & $\%$ & $\mathbf{n}$ & $\%$ & $\mathbf{n}$ & $\%$ \\
\hline $\begin{array}{l}\text { Going for dental } \\
\text { appointment }\end{array}$ & 96 & $78.7 \%$ & 20 & $16.4 \%$ & 6 & $4.9 \%$ \\
\hline $\begin{array}{l}\text { Sitting in the waiting } \\
\text { room }\end{array}$ & 102 & $83.6 \%$ & 14 & $11.5 \%$ & 6 & $4.9 \%$ \\
\hline Having a tooth drilled. & 90 & $73.8 \%$ & 26 & $21.3 \%$ & 6 & $4.9 \%$ \\
\hline Scaling and Polishing & 110 & $90.2 \%$ & 10 & $8.2 \%$ & 2 & $1.6 \%$ \\
\hline $\begin{array}{l}\text { Local anaesthetic } \\
\text { (injection) }\end{array}$ & 86 & $70.5 \%$ & 30 & $24.6 \%$ & 6 & $4.9 \%$ \\
\hline Mean Scores & 97 & $79.3 \%$ & 20 & $16.4 \%$ & 5 & $4.1 \%$ \\
\hline
\end{tabular}




\section{Relationship between Socioeconomic demographics of patients and mean MDAS scores}

The gender of the respondents was associated with dental anxiety with female respondents exhibiting more anxiety than males. This association was however not statistically significant. $(P=0.054)$. The level of education of the respondents was significantly associated with dental anxiety $(P=0.001)$ with respondents with primary education having the greatest level of dental anxiety. The age of the subjects was also significantly associated with dental anxiety $=0.000$. Respondents in the 21-30 years age category had the highest level of anxiety. Single respondents also had the highest level of anxiety $(P=0.036)$ (Table 2$)$.

\section{Frequency breakdown of mean MDAS scores and percentage with MDAS $\geq 19$}

The mean MDAS score was higher in females (11.6 \pm 6.2 ) than males (11.31 \pm 5.1 ). About $4.83 \%$ of females had MDAS $\geq 19$ the highest mean MDAS score $(12.3$ \pm 5.2) was in the 21-30 age category. Single respondents had the highest mean MDAS scores $(12.3 \pm 5.3) \quad$ Subjects with primary educational qualification also had the highest mean MDAS scores $(13.0 \pm 6.6)$ (Table 3 ).

\section{DISCUSSION}

Dental anxiety have been reported to be similar, irrespective of country, culture and other living conditions of patients. $^{22}$ The prevalence of dental anxiety has been shown to range between 4 and $23.4 \% .{ }^{23}$ This study found a prevalence of dental anxiety of $20.5 \%$ and a prevalence of extreme anxiety of $4.1 \%$. The mean MDAS in this study was $11.5 \pm 5.8$. This mean value was lower than that of a previous Nigerian study with a mean MDAS of $12.03 \pm 4.3 .{ }^{21}$ This could be due to a higher proportion of tertiary educated respondents in our sample.

There were more female respondents $(50.8 \%)$ in this study. Female respondents in this study had higher MDAS scores than males and were more severely anxious even though the association was not statistically significant. This was generally in agreement with previous studies. Epidemiological investigations have consistently revealed that a greater proportion of females have specific phobias more than males. Some studies have even shown a prevalence of dental anxiety approximately twice as high for females as for males. ${ }^{24,25}$ Women have lower pain thresholds and less tolerance for pain and may be more open to expressing fears than men. Similarly, females tend to

Table 2: Relationship between Socio-economic characteristics of patients and mean MDAS scores.

\begin{tabular}{|c|c|c|c|c|c|c|c|}
\hline & & \multicolumn{2}{|c|}{ Not anxious } & \multicolumn{2}{|c|}{ Very anxious } & \multicolumn{2}{|c|}{ Extremely anxious } \\
\hline & & $\mathbf{n}$ & $\%$ & $\mathbf{n}$ & $\%$ & $\mathbf{n}$ & $\%$ \\
\hline \multirow[t]{3}{*}{ Gender } & Male & 49 & $40.2 \%$ & 9 & $7.4 \%$ & 2 & $1.6 \%$ \\
\hline & Female & 48 & $39.3 \%$ & 11 & $9.0 \%$ & 3 & $2.5 \%$ \\
\hline & & & & & & & \\
\hline \multirow[t]{5}{*}{ Education } & None & 1 & $0.8 \%$ & 1 & $0.8 \%$ & 0 & $0 \%$ \\
\hline & Primary & 4 & $3.3 \%$ & 4 & $3.3 \%$ & 2 & $1.6 \%$ \\
\hline & Secondary & 30 & $24.6 \%$ & 7 & $5.7 \%$ & 1 & $0.8 \%$ \\
\hline & Tertiary & 62 & $50.8 \%$ & 8 & $6.6 \%$ & 2 & $1.6 \%$ \\
\hline & & & & & & & \\
\hline \multirow[t]{6}{*}{ Age category } & $11-20$ years & 19 & $15.6 \%$ & 6 & $4.9 \%$ & 1 & $0.8 \%$ \\
\hline & $21-30$ years & 23 & $18.9 \%$ & 9 & $7.4 \%$ & 2 & $1.6 \%$ \\
\hline & $31-40$ years & 31 & $25.4 \%$ & 3 & $2.5 \%$ & 2 & $1.6 \%$ \\
\hline & $41-50$ years & 14 & $11.5 \%$ & 2 & $1.6 \%$ & 0 & $0 \%$ \\
\hline & 51 and above. & 10 & $8.2 \%$ & 0 & $0 \%$ & 0 & $0 \%$ \\
\hline & & & & & & & \\
\hline \multirow[t]{4}{*}{ Marital status } & Single & 50 & $41.0 \%$ & 12 & $9.8 \%$ & 4 & $3.3 \%$ \\
\hline & Married & 42 & $34.4 \%$ & 7 & $5.7 \%$ & 1 & $0.8 \%$ \\
\hline & Widowed & 5 & $4.2 \%$ & 1 & $0.8 \%$ & 0 & $0 \%$ \\
\hline & & & & & & & \\
\hline
\end{tabular}


seek dental care more often compared to males and thus may have more frequent dental visits and experience more stressful events during their treatment which may make them more susceptible to dental fear.

Age was significantly associated with dental anxiety and this was most significant in the 21-30 age bracket. Younger people have generally been found to be more anxious than older people individuals. ${ }^{26-28}$ This could be due to the fear of the unknown since many may not have had a previous dental experience. Single respondents in this study who were generally younger also had higher mean MDAS scores. A population-based study by Milgrom et al. ${ }^{29}$ found that $33.3 \%$ became anxious during adolescence or adulthood.

This study demonstrated a high level of dental anxiety in respondents with low educational status. This was in agreement with Peretz \& Moshonov ${ }^{28}$ who found that patients with higher education levels had lower dental anxiety. This was also consistent with the findings of Hallstrom and Halling ${ }^{30}$ who reported a higher prevalence of dental anxiety among individuals of lower education level and social class. Moore et al. similarly found both low education and low income to be risk factors for moderate dental anxiety. People from lower socio-economic backgrounds experience poorer physical health, more psychological problems and have reduced access to resources. ${ }^{30}$ These variables were however not significantly related to extreme dental anxiety.

The most common stimuli associated with dental anxiety are typically injections, the sound/sight/smell of the drill or hand piece, and pain associated with dental treatment. Individuals who are fearful of specific stimuli can readily identify the aspect(s) of dentistry they find most aversive. ${ }^{31}$ Having a tooth drilled and anticipating a local anaesthetic injection elicited the highest mean MDAS scores in this study while sitting in the waiting room and having scaling and polishing done elicited the least scores. A possible explanation

Table 3: Frequency breakdown of mean MDAS scores and percentage with MDAS $\geq 19$.

\begin{tabular}{|c|c|c|c|c|c|}
\hline & $\mathrm{N}$ & $\%$ & Mean & SD & $\% \geq 19$ \\
\hline \multicolumn{6}{|l|}{ Gender } \\
\hline Male & 60 & $49.1 \%$ & 11.3 & 5.1 & $3.3 \%$ \\
\hline Female & 62 & $50.8 \%$ & 11.6 & 6.1 & $4.8 \%$ \\
\hline \multicolumn{6}{|l|}{ Age group (years) } \\
\hline$<20$ years & 26 & $21.3 \%$ & 11.3 & 3.5 & $3.8 \%$ \\
\hline $21-30$ years & 34 & $27.9 \%$ & 12.3 & 5.3 & $5.8 \%$ \\
\hline $31-40$ years & 36 & $29.5 \%$ & 10.0 & 3.3 & $5.5 \%$ \\
\hline $41-50$ years & 16 & $13.1 \%$ & 8.67 & 2.2 & $0 \%$ \\
\hline 51 and above & 10 & $8.2 \%$ & 7.50 & 2.1 & $0 \%$ \\
\hline \multicolumn{6}{|l|}{ Educational status } \\
\hline None & 2 & $1.6 \%$ & 11.3 & 5.7 & $0 \%$ \\
\hline Primary school & 10 & $8.2 \%$ & 13.0 & 6.6 & $20.0 \%$ \\
\hline Secondary school & 38 & $31.2 \%$ & 11.1 & 5.6 & $2.6 \%$ \\
\hline Tertiary education & 72 & $59.0 \%$ & 10.8 & 4.5 & $2.7 \%$ \\
\hline \multicolumn{6}{|l|}{ Marital status } \\
\hline Single & 66 & $54.0 \%$ & 12.3 & 5.3 & $6.1 \%$ \\
\hline Married & 50 & $41.0 \%$ & 11.6 & 5.2 & $2.0 \%$ \\
\hline Widowed & 6 & $5.0 \%$ & 11.1 & 5.8 & $0 \%$ \\
\hline Total & 122 & $100 \%$ & 11.5 & 5.8 & $4.1 \%$ \\
\hline
\end{tabular}


for this is that the drill and anesthetic needle are associated with anticipation of pain. Local anaesthesia is often identified as the major reason for pain during dental treatment. ${ }^{32}$

\section{CONCLUSION}

The findings of this study are not significantly different from those conducted in other climes. It also validates the findings of a previous study conducted in Nigeria. ${ }^{21}$ The best predictors for dental anxiety from this study were, in descending order, age, education, marital status and gender. A rapid screening tool such as the MDAS could be routinely applied on prospective dental patients to determine their level of anxiety. Appropriate non-pharmacologic and pharmacologic strategies could then be targeted at vulnerable respondents to make their dental experience as pleasant as possible.

\section{REFERENCES}

1. Chapman H R. Kirby Turner N. C. Dental fear in children- A proposed model. Br Dent. J. 1999; 187(8):408-12.

2. Seligman, M.E.P., Walker, E.F., \& Rosenhan, D.L. (2001). Abnormal psychology. (4th Ed.). New York (NY): W.W. Norton \& Company, Inc.

3. Agras S, Sylvester D, Oliveau D. The epidemiology of common fears and phobia. Compr Psychiatry 1969; 10: 151-6.

4. Eli I, Uziel N, Blumensohn R, Baht R. Modulation of dental anxiety - the role of past experiences, psychopathologic traits and individual attachment patterns. Br Dent J 2004; 196: 689-94.

5. Locker D, Shapiro D, Liddell A. Overlap between dental anxiety and blood-injury fears: psychological characteristics and response to dental treatment. Behav Res Ther 1997; 35: 583-90.

6. Freeman R. Barrier to accessing and accepting dental care. Br Dent J. 1999;187: 81-84.

7. Woolgrove J, Cumberbatch G. Dental anxiety and regularity of dental attendance. J Dent 1986; 14: 209-213.
8. Doebling S, Rowe MM. Negative perceptions of dental stimuli and their effects on dental fear. JDent Hyg.2000; 74, 110-116.

9. Locker D. Psychosocial consequences of dental fear and anxiety. Community Dent Oral Epidemiol.2003; 23: 144-151.

10. Bedi R, Sutcliffe P, Donnan PT, McConnachie J. The prevalence of dental anxiety in a group of 13- and 14-year-old Scottish children. Int J Paediatr Dent 1992; 2: 17-24.

11. Locker D, Murray Thomson W, Poulton R. Onset of and patterns of change in dental anxiety in adolescence and early adulthood: a birth cohort study. Community Dent Health 2001; 18: 99-104.

12. Stouthard M, Hoogstraten J. Prevalence of dental anxiety in The Netherlands. Community Dent Oral Epidemiol 1990; 18: 139-42.

13. Hakeberg $M$, Berggren $U$, Carlsson SG. Prevalence of dental anxiety in an adult population in a major urban area in Sweden. Commun Dent Oral Epidemiol 1992; 20: 97-101.

14. Hagglin C, Berggren U, Hakeberg M, Hallstrom T, Bengtsson C. Variations in dental anxiety among middle aged and elderly women in Sweden: a longitudinal study between 1968 and 1996. J Dent Res 1999; 78: 1655-61.

15. Doerr PA, Lang WP, Nyquist LV, Ronis DL. Factors associated with dental anxiety. J Am Dent Assoc. 1998; 129: 1111-1119.

16. Ragnarsson B, Arnlaugsson S, Karlsson KO, Magnusson TE, Arnarson EO. Dental anxiety in Iceland: an epidemiological postal survey. Acta Odontol Scand 2003;61:283-288.

17. Humphris GM, Morrison T, Lindsay SJ. The Modified Dental Anxiety Scale: validation and United Kingdom norms. Community Dent Health 1995;12:143-150.

18. Armfield JM, Spencer AJ, Stewart JF: Dental fear in Australia: who's afraid of the dentist? Aust Dent J 2006, 51(1):78-85.

19. Lahti S, Vehkalahti MM, Nordblad A, Hausen H: Dental fear among population aged 30 years and older in Finland. Acta Odontol Scand 2007, 65(2):97-102. 
20. Sofola OO, Uti OG. Barriers in Oral Health Care: Dental anxiety and fear in Nigerian Patients.Nig. Journ. Of Commu.Med. And Pry. Health Care.2003;15:53-9.

21. Arigbede AO, Ajayi DM, Adeyemi BF, Kolude B. Dental anxiety among patients visiting a University Dental Centre. Nig. Dent J. 2011;19(1) 20-24.

22. Armfield, Jason $M$, Spencer, John A. and Stewart, Judy F. Dental fear in Australia: Who's afraid of the dentist? Aust. Dent. Journ.2006; 51:78-85.

23. Kanegane K, Penha SS, Munhoz CD, Rocha $R G$. Dental anxiet y and salivar y cortisol levels before urgent dental care. J Oral Sci 2009; 51:515-520.

24. Locker D. Psychosocial consequences of dental fear and anxiety. Community Dent Oral Epidemiol 2003;31:144-151.

25. Thomson WM, Stewart JF, Carter KD, Spencer AJ. Dental anxiety among Australians. Int Dent J 1996;46:320-324.

26. ter Horst $\mathrm{G}$, de Wit $\mathrm{CA}$. Review of behavioural research in dentistry 1987-1992: dental anxiety, dentist-patient relationship, compliance and dental attendance. Int Dent J 1993;43:265-278.
27. Locker D, Liddell A. Stability of dental anxiety scale scores: a longitudinal study. Community Dent. and Oral Epidemiol. 1995; 23, 259-61.

28. Peretz B, Moshonov J. Dental Anxiety among Patients Undergoing Endodontic Treatment. J. Endo. 1998; 24(6), 435-7.

29. Milgrom $P$, Weinstein $P$, Heaton LJ. Treating fearful dental patients: a patient management handbook. 3rd edn. Seattle, WA: Dental Behavioral Resources, 2009.

30. Hallstrom T, Halling A. Prevalence of dentistry phobia and its relation to missing teeth, alveolar bone loss and dental care habits in an urban community sample. Acta Psychiatrica Scandinavica.1984; 70, 438-46.

31. Moore R, Birn H, Kirkegaard E, Brodsgaard I, Scheutz F. Prevalence and characteristics of dental anxiety in Danish adults. Community Dent Oral Epidemiol 1993;21:292-296.

32. Willershausen $B$, Azrak A, Wilms S: Fear of dental treatment and its possible effects on oral health. Eur J Med Res 1999; 4(2):72-77. 